\title{
The Role of College Counselors in the Construction of Study Style
}

\author{
Shuqiong $\mathrm{Xu}^{1, \mathrm{a}}$, Duanchun Shen ${ }^{2, \mathrm{~b}}$ \\ ${ }^{1}$ School of Mechanical Engineering, Linyi University, \\ ${ }^{2}$ School of informatics, Linyi University \\ Linyi, Shandong 276005 \\ a xushuqiong11@sina.com, bshenduanchun@lyu.edu.cn
}

Keywords: Role; College student; Counselors; Construction; Study Style.

\begin{abstract}
The construction of study style is an important aspect in the university construction, establishing good study style becoming the key point to reach undergraduates' prime. Counselors have to strengthen the propaganda and implement university discipline system through strengthen the political thought education, coordinating the various factors influencing the construction of study style, exerting the role of student backbone and student associations. Pay attention to students who have difficulty in learning, attaching great importance to the aspects such as the influence of the network to promote the formation of good style of study.
\end{abstract}

\section{Introduction}

The fine study style in universities will have a subtle influence on every student, it make the students have salutary influence of education. The influence has a driving force in improving the quality of education and promoting the talent training quality. These factors such as school management team, teachers, instructors, students, society and students' parents play different roles in the construction of study style with college counselors playing an extremely important role.

\section{The current problems of the construction of study style}

At present, there have been some concern in the the academic discipline. Mainly displays in: students learning goals are not clear, lax, students' learning attitude being not correct and a lot of cheating in the exam, the students team has the trend of polarization. The classroom teaching is less if attractive, and students truancy phenomenon is relatively common, etc.

\section{The role of counselor in the study style construction}

Higher school counselor as an important part of teachers' team and management team is the backbone to carry out the ideological and political education, with becoming the organizers, practitioners and mentors in the management of daily ideological and political education for university students. Instructors should strive to become a mentor and bosom friends in the healthy growth of students. It is emphasized that the professional characteristics of counselor should be fully as the navigator in the life development of college students and the mentor in learning, which is defined and required in "The institutions of higher learning counselor team construction regulations” implemented by the national ministry of education in September 2006[1]. According to the counselors' responsibilities, working characteristics and the problems existing in the academic discipline as well as the factors that influence the construction of study style, counselors should promote the formation and develop a good study style through the following six aspects: 


\subsection{Strengthen the political education, and promote students' motive power in learning}

The students' learning attitude will become regular and learning goals clear through strengthen the political thought education. There is a direct relationship between the phenomenon that students lack learning motivation, learning attitude being not correct, relaxation of discipline and their understanding of learning , ideological awareness, world view. Counselors should carry out ideological education for students, for example, establish a typical, carry forward the healthy atmosphere, make the students to set up the broad ideal and set up the correct learning attitude to cultivate the students' learning interest and initiative, stimulate the intrinsic motivation.

Strengthen the professional education and guide students to correctly treat the learning profession. At present, there are quite a few students being weariness in many universities. They can't understand and treat the specialty correctly, feel no future for the major, or don't like their major, so the phenomenon such as learning is not at ease, achievement is not ideal and disgusted learning appeared. So instructors should undertake continuing professional education, and launch all-round, multi-level professional ideal education for the students. Only students set up the correct professional idea, can they learn positively, assiduously, initiative and energetically explore, so form good learning habits to promote the construction of good study style.

Adhere to the correct guidance and improve students' self-consciousness in construction of study style. Instructors should pay more attention to the corpus function of students in the school tradition construction, attache great importance to the students' self education and self-management to make them consciously improve their own quality. Let the students realize that their own growth is not only related to the training and education of school and teachers, but with their own hard work. Only in this way can make the students' self-education, self-management, self-service and make them clear that the good study style is not only to the school leaders and teachers, but closely related to themselves, and it's the biggest gains in learning life[2] [3] [4].

\subsection{Coordinate the various factors of school and promote the formation of good study style}

Construct a harmonious campus and create the basis of good style of study. College counselor is the bridge between school and students, teachers and students, students and students, therefore, it's repetitive to have a high-quality counselor team as a guarantee in construction of a harmonious campus. Instructors could make full use of profound history and tradition, colorful cultural campus life to rich human landscape, and elegant campus environment of the school to exerts a subtle influence on students and education, making the students agree with the present situation and the campus culture, realize the harmony of man and campus environment in the identity and create a good study style in the harmonious campus atmosphere.

Strengthen the management of students' dormitory is an important job in the construction of harmonious campus. Instructors should often deep into the student dormitory, in the process of visiting the dormitory and communicating with students, as well as careful observation to understand the student's basic situation and ideological dynamic, timely find bad phenomenon and safe hidden trouble, so pay special attention to the dormitory culture construction and build good teaching atmosphere. Counselors should adopt various forms to guide student's thought positively for the period of the hot topics, introduce the students' enthusiasm and focus gradually to the construction of good study style.

Coordinated with the teacher and promote study with teaching manner. The teacher's teaching manner play a good role in promoting college students' learning. Teachers' academic attainments can pursue scientific attitude college students, so as to establish lofty ideal to establish a high level of learning goals. Good education teaching activities can stimulate students' interest in learning directly, awaken the potential learning motivation, and thereby to stabilize the lasting learning enthusiasm. Teachers' comprehensive quality can edify students all-roundly, multi-levelly and subtly, and transformed to the good learning quality of college students themselves gradually. The success or not 
of the study style construction depended on the learning atmosphere which depended on the teaching quality. Instructors may strengthen the connection between the teachers and students by holding the inclass lectures and seminars, encourage students to communicate with teachers and feedback to students' learning situation in time to professional teachers. Coordinated with the teacher and promote the construction of study style.

Coordinate with the parents of the students and improve influence of the study style. Instructors must strengthen the contraction with the parents of the students to form resultant force of education. Counselors can through We-chat, QQ, telephone and other contact information to communicate with parents of students, and achieve parent-school cooperative, parent-school synchronization for students in the education and management aspects. Counselor can make a term summary of the work, thoughts, life and other various aspects situation of students as an overall rating, and give it to parents to make the parents realize the school situation, so as to assist schools by supervising and urging children and promote the development of good study style[5] [6] .

\subsection{Develop the role of student backbone and the student community, and promote the co nstruction of good study style}

Pay attention to the cultivation of the class cadre and strengthen the leading role of the key members in the school tradition construction. College student party members and student cadres must strive to learn each subject, and make their scores be the best to play a leading role in learning. Each party members student should contact a motivate student, and help an underachiever; Wealthy party members students can also contact a poor for funding. Develop the role of the party member's exemplary in students work solidly, and develop a leading role of the party and students cadre in the construction of study style.

Develop the role of the students' association, and enrich the connotation of the study style construction. Forming a community with professional characteristics to launch community activities can cultivate people's interests, develop personal expertise and skills, apply the studied professional knowledge to practice which played a positive role of promoting the all-round development of students. College society also has the role to cultivate the college students team spirit and self survival ability. Every activity is a collective, rather than individual behavior. A club has its own organization, and has its own constitution, a president, communications department, planning department, organization department, propaganda department, etc. How to coordinate the relationship between the various departments, how to integrate resources to maximize the power of the community of numerous members, how to make new action activities and how to attract other club students, and so on, which are not the individuals kills that can acquire from the classroom or on the social practice. Exercising in a society is the best way to cultivate the students' team spirit and survival ability.

Therefore, for building contented and rich good study style, the counselor must give full play to the positive role of college students' community, the enthusiasm of students, and promote study style of unity, diligence, truth-seeking and innovation. Encourage students to participate in various campus activities to enrich the content of study style. Students have the second classroom activities which include art, music, sports, calligraphy, fine arts, social practice, community activities, etc. Counselors should organize these activities for the purpose that promote study style construction. Carrying out rich and colorful extracurricular life can improve the students' humanities accomplishment, and stimulate students' interest in learning, cultivating students' ability of practice innovation, thereby form the strong academic atmosphere gradually and improve the study ethos of the colleges and universities [7] [8].

\subsection{Strengthen the propaganda and implementation of university discipline system, and guarantee the improvement and implementation of good study style}

Vigorously promote and implement the rules and regulations to grantee the construction of study style. Before the semester the instructor should propagandize the regulations and management measures to 
the students comprehensively, and make students clear what school advocates and opposed. Regulate the behavior of students with system, and strengthen the self-management of students. In the daily management, counselor should be non-distinct, punishing for worse, rewarding for better, and improve students' self-control to form a good learning atmosphere.

Refine the system construction, and constructs the system of class management. Pay attention to the optimization of classroom atmosphere, for example, design "attendance table of study style in class ", etc. For the bad behavior of students in class, the counselor should hardness and curl it according to the rules and regulations of the school education seriously. Bring the attendance of study style in class into the evaluation system of comprehensive appraisal. Choosing excellent and scholarship selection conditions should link to students' classroom performance, and increase the weight of academic achievement to the comprehensive evaluation. Do a good job of study style construction in basic level to make the school tradition construction into effect.

Value the examination discipline and examination manners education. The examination is an important part of the study style. There will never be a good study style without good examination manners and a really competitive attitude of realistic deposit without hard working. Instructors must carry on the mobilization before exams, and require all the students concentrate on preparing, at the same time, released disciplinary punishment decision of the previous rigged students. Put an end of the phenomenon violating the examination discipline by warming, caution and education. Adopts the honest commitment system of examination, creating no monitor examination room, and build good exam atmosphere "honesty honor, shameful cheating" among students[9] [10].

\subsection{Pay attention to students with learning disabilities, and promote the improvement of the good study style}

Some students always have violations such as being late for class or truancy, absenteeism and others in morning reading and assembly etc. This part of the students' learning behavior will affect the other students, and affect the study style. Once students have violations, instructors should communicate with the students timely, and carefully help students find out the reasons, analyze the harm, and put forward a clear and specific requirements for the student. Check and supervise reform situation of students, standardize students all aspects of performance in the future to arrest the spread of unhealthy phenomenon and guarantee the style construction. Through the unremitting efforts, help the junior students effectively curb the occurrence of being late, truancy, discipline and other bad behavior. Arouse the mutual supervision and influence of class to make this part of the students to consciously regulate their own behavior, so finally enhance the achievement of study style construction[11].

\subsection{Attach importance to the influence of the network, and lead students to learn by using the internet to promote study style development}

With the continuous increasing of campus network, the internet for learning have become the powerful tool to improve the teaching effect of classroom and learning efficiency. Counselors should guide and educate students to correctly use the Internet effectively, and take active measures to resist unhealthy information on the net. Counselor should intervene the most popular areas of students, such as We Chat group, mobile fetion, QQ, etc. to understand thought tendency of the students, thus strengthen the pertinence of work. At the same time, the counselor should focus on site which students hit highly, and understand all kinds of social hot spot phenomenon, cultural zeitgeist, and research the generated changes information of the student thought, seeking countermeasures in time, and increase the ideological and political work prescient. 


\section{Summary}

The existing problems in the study style should be improved by the Counselors. According to the factors that affect the construction of the study style, counselors should work in these aspects to promote the formation and development of the fine study style.

\section{References}

[1] The education of the People's Republic of China ministry make 24. Ordinary institutions of higher learning counselor team construction regulations, July, 2004

[2] Rui Wang, Fang Zhao. About the thinking of the counselor role strengthening students' study style construction in college. Course Education Research,2015(23)

[3] Cunfu Gao, Zhaofu Tian.The thinking of the counselor to promote study style construction under the new media era, Education and Vocation, 2014(23)

[4] Jie Liu, Lan pang. A Survey on the Undergraduate Study and the Revelation to the University Study Style Construction. Journal of China University of Geosciences(Social Sciences Edition), 2014(3)

[5] Yunxian Li. Improving campus cultural atmosphere and promoting the construction of study style. Research on Education of Shanghai University of Engineering Science, 2006(2).

[6] Jiamao Zheng, Xiaohui Pan. On Improving Attitude of Study of Undergraduate. Journal of Tsinghua Education, 2013(4)

[7] Kejin Deng. A probe into thinking of student work in colleges and universiries under the new situation. Journal of Changchun University, 2013(4)

[8] Xin Zhao. Research on the Duties and its Performing of Counselors in Chinese Universities in the New Times. Hunan Normal University, 2012

[9] Li Liu, Jiahui Huang, Xiaolin Liu. The role of counselors in university study style construction and countermeasures research - based on the college students study survey in dalian. Ideological and Political Education Research.2010(04)

[10] Gu Gong. On the Leading Role of Counselors in the Construction of Study Ethos. Journal of Qilu Normal University. 2014(05)

[11] Jing Li,Qi He, The investigation and analysis of the weariness phenomenon of college students. Journal of Lanzhou University(Social Sciences), 2005(1). 